\title{
Role of urinary podocalyxin in early diagnosis of diabetic nephropathy
}

\author{
IRENA KOSTOVSKA ${ }^{1}$, KATERINA TOSHESKA TRAJKOVSKA ${ }^{1}$, SVETLANA CEKOVSKA $^{1}$, SONJA TOPUZOVSKA ${ }^{1}$, \\ JULIJANA BREZOVSKA KAVRAKOVA ${ }^{1}$, GOCE SPASOVSKI ${ }^{2}$, OGNEN KOSTOVSKI ${ }^{3}$, DANICA LABUDOVIC ${ }^{1}$
}

\author{
${ }^{1}$ Department of Medical Biochemistry, Faculty of Medicine, Str. 50 Divizija 6, 1000, Skopje, North Macedonia \\ ${ }^{2}$ University Clinic of Nephrology, Faculty of Medicine, Str. Mother Teresa 17, 1000, Skopje, North Macedonia \\ ${ }^{3}$ University Clinic of Abdominal Surgery, Faculty of Medicine, Str. Mother Teresa 17, 1000, Skopje, North Macedonia
}

\begin{abstract}
Introduction. Podocyte injury has been reported as an early feature of DN therefore, the assessment of podocyte injury can be accomplished by estimation of podocalyxin in urine. This study aimed to estimate the urinary podocalyxin levels and to determine the sensitivity and specificity of this biomarker for early detection of DN.

Materials and methods. A total of 90 patients with type 2 diabetes mellitus (T2DM) were included in this cross-sectional study. Sixty of them were without diagnosed DN, and 30 with diagnosed DN. A control group consisted of 30 healthy subjects. All patients with T2DM were divided into three subgroups according to urinary microalbumin/creatinine ratio $(\mathrm{UM} / \mathrm{CR})$ : normoalbuminuric, microalbuminuric and macroalbuminuric patients. Urine samples, were used for measurement of podocalyxin by ELISA, creatinine and microalbumin. Fasting venous blood samples was collected for biochemical analyses.

Results. The levels of urinary podocalyxin (u-PDX) were higher in patients with T2DM compared to control subjects and a statistically significant difference among studied subgroups regarding $\mathrm{u}-\mathrm{PDX}$ was found $(\mathrm{p}<0.05)$. Levels of $\mathrm{u}-\mathrm{PDX}$ are increasing gradually with the degree of DN $(\mathrm{p}<0.029)$. $\mathrm{u}$-PDX levels were positively correlated with $\mathrm{UM} / \mathrm{CR}(\mathrm{r}=0.227, \mathrm{p}=0.002)$. A cut-off level of $43.8 \mathrm{ng} / \mathrm{ml} \mathrm{u}$-PDX showed $73.3 \%$ sensitivity and $93.3 \%$ specificity to detect DN in early stage. A cut-off level of $30 \mathrm{mg} / \mathrm{g} \mathrm{UM} / \mathrm{CR}$ showed $41.5 \%$ sensitivity and $90 \%$ specificity in predicting DN. u-PDX was elevated in $48,2 \%$ of normoalbuminuric patients.

Conclusion. Urinary podocalyxin be useful and more sensitive and specific marker in early detection of DN than microalbuminuria.
\end{abstract}

Key words: diabetic nephropathy, microalbumin; podocalyxin, ROC analysis, podocytes.

\footnotetext{
What is new/what is important?

- Diabetic nephropathy (DN) remains as the most common cause of end-stage renal disease (ESRD) worldwide

- Podocyte injury has been reported as an early feature of DN therefore, the assessment of podocyte injury can be accomplished by measurement of podocyte specific protein - podocalyxin in urine

- Urinary podocalyxin (u-PDX) was higher than the cut-off value in $48,2 \%$ of normoalbuminuric patients with T2DM. ROC curve plotted for u-PDX levels showed that at a cut-off level of $43.8 \mathrm{ng} / \mathrm{ml} \mathrm{u}$-PDX revealed $73.3 \%$ sensitivity and $93.3 \%$ specificity to detect DN in early stage

- Urinary podocalyxin could be useful and more sensitive and specific marker in early detection of DN than microalbuminuria
}

\section{INTRODUCTION}

Diabetic nephropathy (DN) is a serious and the most common complication in patients with type 2 diabetes mellitus (T2DM). It is important to note that $\sim 40 \%$ of patients with T2DM develop DN. $\mathrm{DN}$ is characterized by proteinuria, hypertension, and progressive reductions in kidney function. $\mathrm{DN}$ as a leading cause of end-stage renal disease (ESRD) has become a public health concern increasing the number of patients requiring renal replacement therapies (dialysis or transplantation) [1,2]. Early detection of DN and early intervention in DN can help to slow progression into ESRD. Screening for DN should be initiated immediately at the time of diagnosis because approximately $3 \%$ of patients with newly diagnosed T2DM already have overt nephropathy [3]. Although microalbuminuria remains as a gold standard for early detection of $\mathrm{DN}$, there are attendant shortcomings of microalbuminuria as a early marker of $\mathrm{DN}$ and its predictive powers are limited. Some patients without microalbuminuria show advanced renal pathological changes, indicating that microalbuminuria may not be an ideal marker 
for early detection of DN. In certain circumstances, patients with T2DM develop progressive loss of kidney function before the onset of microalbuminuria. Thus, microalbuminuria is a non-specific marker, and nonsensitive marker for early detection of $\mathrm{DN}$, in patients with T2DM $[4,5]$. There have been great attempts in recent years to identify more sensitive and specific biomarkers than microalbuminura for early detection of DN.

Podocyte injury play an important role in pathological mechanisms of DN. The typical signs of podocytopathy are podocytes hypertrophy, foot process effacement, epithelial-mesenchymal transdifferentiation (EMT), detachment from the glomerular basal membrane and apoptosis $[6,7]$. Early stage of DN is characterised by a progressive reduction in podocyte number, disappearance of their foot processes, shedding of podocytes through urine, and damage of filtration slit-diaphragm, which lead to proteinuria [8-10]. Therefore, the presence of podocytes and their specific proteins in urine may be considered as potential markers in early detection of DN. Currently, new markers for early detection of DN are being evaluated and most of the studies are focused on the podocyte-specific protein such as podocalyxin, nephrin, synaptopodin, podocin, mindin, etc. [11-15].

Podocalyxin (PDX) is an anionic transmembrane sialoglycoprotein of podocytes, member of the CD34 (Cluster of Differentiation 34) family. Podocytes are visceral epithelial cells that contribute to the formation of the glomerular filtration barrier (GFB) [16]. PDX is a sialoglycoprotein and a major component of podocyte glycocalyx, thus, it form the electrostatic barrier of GBM to plasma proteins $[17,18]$. Damage of podocyte and their shedding through urine result in presence of PDX in urine (u-PDX), rendering it as a possibly useful marker in early diagnosis of DN [19]. This study aimed to estimate the u-PDX levels and to determine the sensitivity and specificity of this biomarker for early detection of DN.

\section{MATERIALS AND METHODS}

A total of 90 patients with T2DM were included in this cross-sectional study. The study population consisted of two subgroups, first subgroup patients with T2DM who were diagnosed with DN $(\mathrm{n}=30)$, and second subgroup patients with T2DM who were not diagnosed with $\mathrm{DN}(\mathrm{n}=60)$. As a control group were used a total of 30 healthy subjects. The study was conducted from March 2016 to May 2017 at the Department of Medical and Experimental Biochemistry, Faculty of Medicine in Skopje, North Macedonia.

Patients with T2DM and diagnosed DN were recruited from the University Clinic of Nephrology at the Faculty of Medicine in Skopje. Inclusion criteria for patients with T2DM and DN were clinically manifested DN, represent by certain levels of kidney function - an abnormality in serum creatinine levels and glomerular filtration rate (GFR), presence of macroalbuminuria or microalbuminuria and elevated arterial blood pressure [20].

Patients with T2DM but without diagnosed DN were recruited from the Primary Health Care Offices. Inclusion criteria for this group of patients were new-onset cases of T2DM without clinically tested and approved DN, absence of pregnancy in women and the absence of any other type of kidney disease. All patients with T2DM were diagnosed and controlled by the Center of Diabetes at the University Department of Endocrinology and Metabolic Diseases, Faculty of Medicine in Skopje.

All patients with T2DM $(n=90)$ were divided into three subgroups according to urinary microalbumin to creatinine ratio $(\mathrm{UM} / \mathrm{CR})$ :

1. patients with normoalbuminuria - UM/CR $<30 \mathrm{mg} / \mathrm{g}(\mathrm{n}=56)$,

2. patients with microalbuminuria - UM/CR $30-300 \mathrm{mg} / \mathrm{g}(\mathrm{n}=25)$

3. patients with macroalbuminuria $-\mathrm{UM} / \mathrm{CR}$ $>300 \mathrm{mg} / \mathrm{g}(\mathrm{n}=9)$

Classification was performed according to guidelines of KDIGO - Kidney Disease: Improving Global Outcomes-giudelines from 2012 [21].

Subgroup of patients with T2DM without diagnosed DN consisted of 31 patients with microalbuminuria and 29 with normoalbuminuria, while a subgroup of patients with T2DM with diagnosed DN consisted of 9 patients with macroalbuminuria and 21 with microalbuminuria.

Urine samples $(10 \mathrm{ml})$ were collected in plastic tubes, without additives. First in fresh urine samples was performed chemical analysis by using urinary strips, than microalbumin levels by turbidimetric method, and creatinine levels by Jaffe reaction were measured on biochemical analyzer ChemWell (2910 Awareness Technology, Inc.). The rest of the urine samples were clarified by centrifugation at 3,000 rpm, $10 \mathrm{~min}$ and froze in Eppendorf tubes at $-80 \mathrm{C}$ until estimation of $\mathrm{u}-\mathrm{PDX}$.

Blood samples were drawn from an antecubital vein in the morning after overnight fasting. Samples 
were centrifugated at 3,000 rpm, 10 minutes, and collected in Eppendorf tubes.

The UM/CR was defined as the urinary albumin value divided by the urinary creatinine concentration $(\mathrm{mg} / \mathrm{g})$. Glomerular filtration rate (eGFR) was estimated using the Cocroft and Gault formula [22].

u-PDX was estimated using commercially available ELISA kits (Exocell Inc., Philadelphia, PA). Urine samples were diluted with dilution buffer provided by the ELISA kits in a ratio of 1:2 for u-PDX. Samples were measured in duplicate. The method for estimation of u-PDX was an indirect competitive ELISA, wherein polyclonal antibodies against u-PDX were used. u-PDX (antigen) and immobilized PDX antigens (at the bottom of polystyrene plates) competed for anti-u-PDX rabbit antibodies. Antirabbit HRP (HRP - horseradish peroxidase) conjugate was used for detection of bounded antibodies. Unbounded antibodies were removed by washing, and the remaining bounded antibodies to immobilized u-PDX antigens were measured photometrically at $450 \mathrm{~nm}$ wavelength. The intensity of the colour was inversely proportional to the concentration of u-PDX. The concentration of u-PDX was read from a standard curve constructed using commercially available standards. The values are expressed as $\mathrm{ng} / \mathrm{ml}$.

The blood samples were collected for estimation of urea, creatinine, glucose, total protein, and albumin. Blood parameters were measured photometrically on biochemical analyzer ChemWell. Medical history and information on sex, age, height, weight, duration of the disease, blood pressure, and glycaemic control were obtained by a completed patients' questionnaires.
Written informed consent was obtained from all participants. The protocol of this study was conducted following the ethical principles of the current Declaration of Helsinki and was approved by the Ethical Committee of the Faculty of Medicine in Skopje, North Macedonia (No. 03-5515/8 from 09.12.2015).

Statistical analysis was performed by using the IBM SPSS Statistics for Windows, version XX (IBM Corp., Armonk, N.Y., USA) and MedCalc for Windows, version 15.0 (MedCalc Software, Ostend, Belgium). We performed statistical analysis using Kolmogorov-Smirnov test, Mann-Whitney U test, Jonckheere-Terpstra test, ONE-way analysis of variance (ANOVA), Kruskal-Wallis test, Kendall's tau-b ( $\tau \mathrm{b})$ correlation and Receiver Operating Characteristic (ROC) analysis. p-value $<0.05$ was considered to be statistically significant.

\section{RESULTS}

\section{COMPARISON OF CLINICAL AND LABORATORY DATA AMONG THE STUDY SUBGROUPS}

Our results showed that there was significant difference among subgroups regarding to all examined clinical ana laboratory data, age, duration of disease, body mass index (BMI), blood glucose, glycated hemoglobin $(\mathrm{HbAlc}), \mathrm{UM} / \mathrm{CR}$, total proteins, albumins, blood urea, serum creatinine, eGFR, and u-pDX. Comparison of clinical and laboratory data among the subgroups of patients with T2DM divided according to UM/CR and healthy subjects are shown in Table 1 , while comparison of clinical and laboratory data among subjects divided according to diagnosed DN and healthy subjects are shown in Table 2.

Table 1

Comparison of clinical and laboratory data among subgroups of patients with T2DM divided according to $\mathrm{UM} / \mathrm{CR}$ and healthy subjects

\begin{tabular}{|l|c|c|c|c|c|}
\hline & $\begin{array}{c}\text { Macro } \\
\text { albuminuria }\end{array}$ & $\begin{array}{c}\text { Micro } \\
\text { albuminuria }\end{array}$ & $\begin{array}{c}\text { Normo } \\
\text { albuminuria }\end{array}$ & $\begin{array}{c}\text { Healthy } \\
\text { subjects }\end{array}$ & p-value \\
\hline Age (years) & $59.1 \pm 10.6$ & $57.2 \pm 8.2$ & $57.4 \pm 6.9$ & $47.8 \pm 9.3$ & 0.005 \\
\hline Duration of disease (years) & $13 \pm 6.7$ & $8.5 \pm 6.5$ & $4.8 \pm 4.2$ & $/$ & $<0.05$ \\
\hline BMI $\left(\mathrm{kg} / \mathrm{m}^{2}\right)$ & $29.5 \pm 5.6$ & $28.8 \pm 3.6$ & $28.7 \pm 4.0$ & $25.6 \pm 3.8$ & $<0.05$ \\
\hline Glucose $(\mathrm{mmol} / \mathrm{L})$ & $9.9 \pm 3.9$ & $8.1 \pm 2.9$ & $6.8 \pm 2.4$ & $4.2 \pm 1.1$ & $<0.05$ \\
\hline UM/CR $(\mathrm{mg} / \mathrm{g})$ & $437.8 \pm 170.8$ & $89.6 \pm 57.9$ & $12.1 \pm 6.9$ & $15.1 \pm 15.4$ & $<0.05$ \\
\hline HbA1c $(\%)$ & $7.9 \pm 0.9$ & $7.4 \pm 1.6$ & $6.9 \pm 1.1$ & $4.7 \pm 0.4$ & 0.025 \\
\hline Total proteins $(\mathrm{g} / \mathrm{L})$ & $72.1 \pm 8.1$ & $64.1 \pm 11.4$ & $62.4 \pm 10.5$ & $73.7 \pm 5.8$ & $<0.05$ \\
\hline Albumin $(\mathrm{g} / \mathrm{L})$ & $39 \pm 4.3$ & $36.2 \pm 9.2$ & $37.5 \pm 6.5$ & $46.4 \pm 2.9$ & $<0.05$ \\
\hline Urea $(\mathrm{mmol} / \mathrm{L})$ & $7.9 \pm 2.1$ & $8.4 \pm 5.4$ & $6.7 \pm 1.9$ & $4.3 \pm 1.1$ & $<0.05$ \\
\hline Creatinine $(\mu \mathrm{mol} / \mathrm{L})$ & $109.5 \pm 7.5$ & $81.5 \pm 15.1$ & $75.9 \pm 13$ & $75.1 \pm 14.6$ & $<0.05$ \\
\hline eGFR $\left(\mathrm{ml} \mathrm{min}{ }^{-1} 1.73 \mathrm{~m}^{-2}\right)$ & $48.2 \pm 12.5$ & $65 . \pm 19.6$ & $67.5 \pm 12.5$ & $91.3 \pm 5.9$ & $<0.05$ \\
\hline u-PDX $(\mathrm{ng} / \mathrm{ml})$ & $67,5 \pm 17,4$ & $58,8 \pm 26,2$ & $51,1 \pm 54,4$ & $27,1 \pm 12,8$ & $<0.05$ \\
\hline
\end{tabular}

Results are shown as mean \pm SD. BMI - body mass index, UM/CR - urinary microalbumin to creatinine ratio, HbA1c - glycated haemoglobin A1c, eGFR - (estimated Glomerular Filtration Rate), u-PDX - urinary podocalyxin. 
Table 2

Comparison of clinical and laboratory data among patients with T2DM divided according to diagnosed DN and healthy subjects

\begin{tabular}{|l|c|c|c|c|}
\hline & $\begin{array}{c}\text { T2DM patients with } \\
\text { diagnosed DN }\end{array}$ & $\begin{array}{c}\text { T2DM patients } \\
\text { without diagnosed DN }\end{array}$ & $\begin{array}{c}\text { Healthy } \\
\text { subjects }\end{array}$ & p-value \\
\hline Age (years) & $55.8 \pm 10.1$ & $57.9 \pm 6.7$ & $47.8 \pm 9.3$ & $<0.05$ \\
\hline Duration of disease (years) & $10.7 \pm 6.9$ & $4.9 \pm 4.5$ & $/$ & $<0.05$ \\
\hline BMI $\left(\mathrm{kg} / \mathrm{m}^{2}\right)$ & $28.8 \pm 4.2$ & $28.7 \pm 4.1$ & $25.6 \pm 3.8$ & 0.002 \\
\hline Glucose $(\mathrm{mmol} / \mathrm{L})$ & $9.3 \pm 3.6$ & $6.8 \pm 2.3$ & $4.2 \pm 1.1$ & $<0.05$ \\
\hline UM/CR $(\mathrm{mg} / \mathrm{g})$ & $209.5 \pm 206.1$ & $16.9 \pm 18.9$ & $15.1 \pm 15.4$ & $<0.05$ \\
\hline HbA1c $(\%)$ & $7.7 \pm 1.6$ & $6.9 \pm 1.1$ & $4.7 \pm 0.5$ & 0.020 \\
\hline Total proteins $(\mathrm{g} / \mathrm{L})$ & $69.5 \pm 9.9$ & $61.3 \pm 10.8$ & $73.7 \pm 5.8$ & $<0.05$ \\
\hline Albumin $(\mathrm{g} / \mathrm{L})$ & $38.3 \pm 9.3$ & $36.6 \pm 6.3$ & $46.4 \pm 2.8$ & $<0.05$ \\
\hline Urea $(\mathrm{mmol} / \mathrm{L})$ & $8.3 \pm 5.3$ & $6.7 \pm 2.1$ & $4.3 \pm 1.1$ & $<0.05$ \\
\hline Creatinine $(\mu \mathrm{mol} / \mathrm{L})$ & $94.1 \pm 18.1$ & $74.9 \pm 12.1$ & $75.1 \pm 14.6$ & $<0.05$ \\
\hline eGFR $\left(\mathrm{ml} \mathrm{min}{ }^{-1} 1.73 \mathrm{~m}^{-2}\right)$ & $61.1 \pm 21.8$ & $67.1 \pm 12.5$ & $91.3 \pm 5.9$ & $<0.05$ \\
\hline u-PDX $(\mathrm{ng} / \mathrm{ml})$ & $70,6 \pm 75,1$ & $45,6 \pm 21,2$ & $27,1 \pm 12,8$ & $<0.05$ \\
\hline
\end{tabular}

Results are shown as mean \pm SD. BMI - body mass index, UM/CR - urinary microalbumin to creatinine ratio, HbA1c - glycated haemoglobin A1c, eGFR - (estimated Glomerular Filtration Rate), u-PDX - urinary podocalyxin.

\section{COMPARISON OF U-PDX LEVELS AMONG SUBGROUPS OF PATIENTS WITH T2DM AND HEALTHY SUBJECTS}

A comparison of u-PDX levels among subgroups of patients divided according to UM/CR and healthy subjects was performed using the KruskalWallis test. The level of u-PDX was significantly elevated in all subgroups of patients divided according to $\mathrm{UM} / \mathrm{CR}$ compared to healthy subjects $(\mathrm{p}<0.05)$. A non-parametric Jonckheere-Terpstra test showed that $\mathrm{u}-\mathrm{PDX}$ is increasing gradually with the degree of DN $(z=2.178, p<0.029)$. The results are shown in Figure 1. The comparison of levels of u-PDX among subgroups of patients divided according to diagnosed DN and healthy subjects was statistically significant $(p<0.05)$. The results are shown in Figure 2.

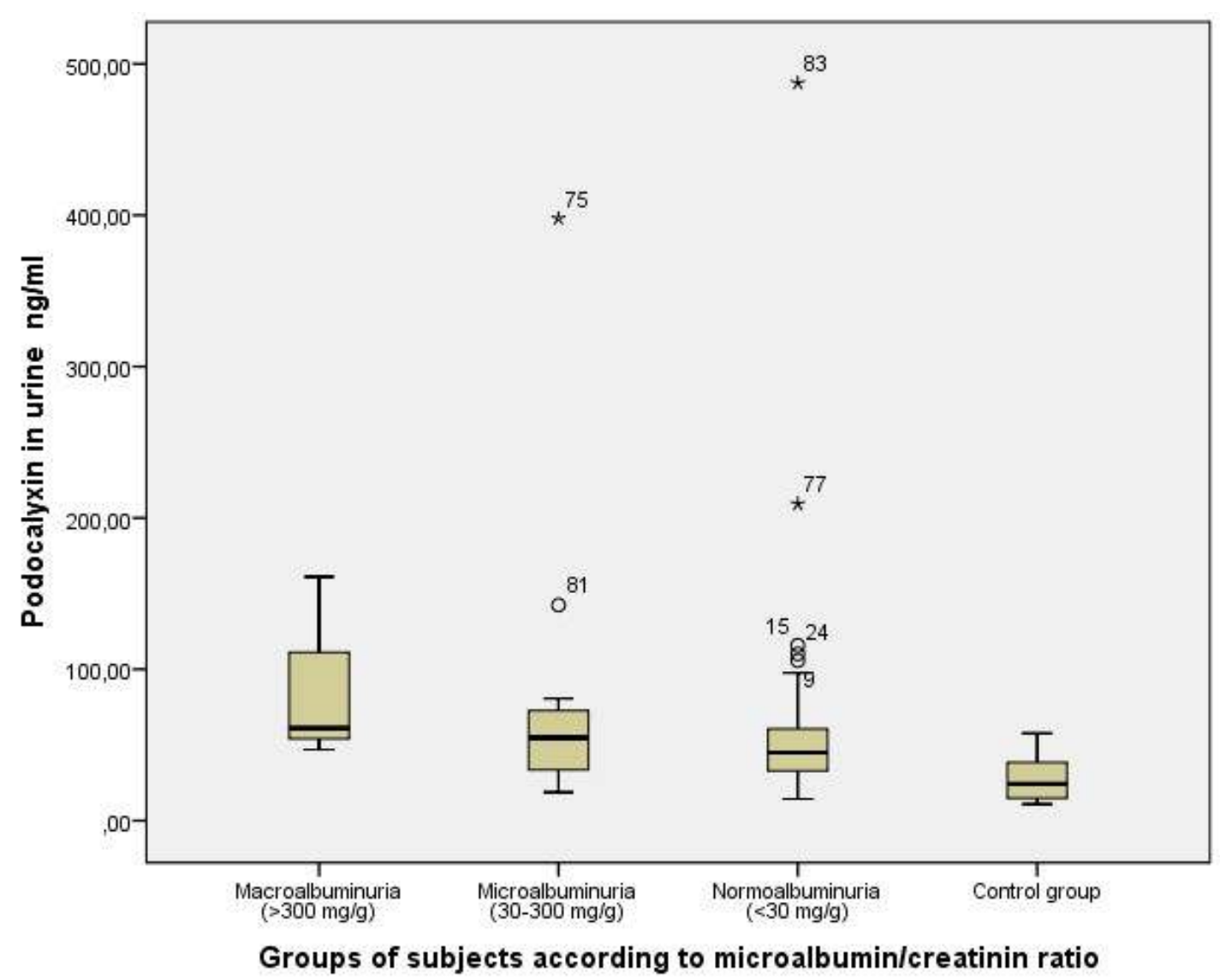

Figure 1. Comparison of u-PDX in subgroups of subjects divided according to UM/CR and healthy subjects. 


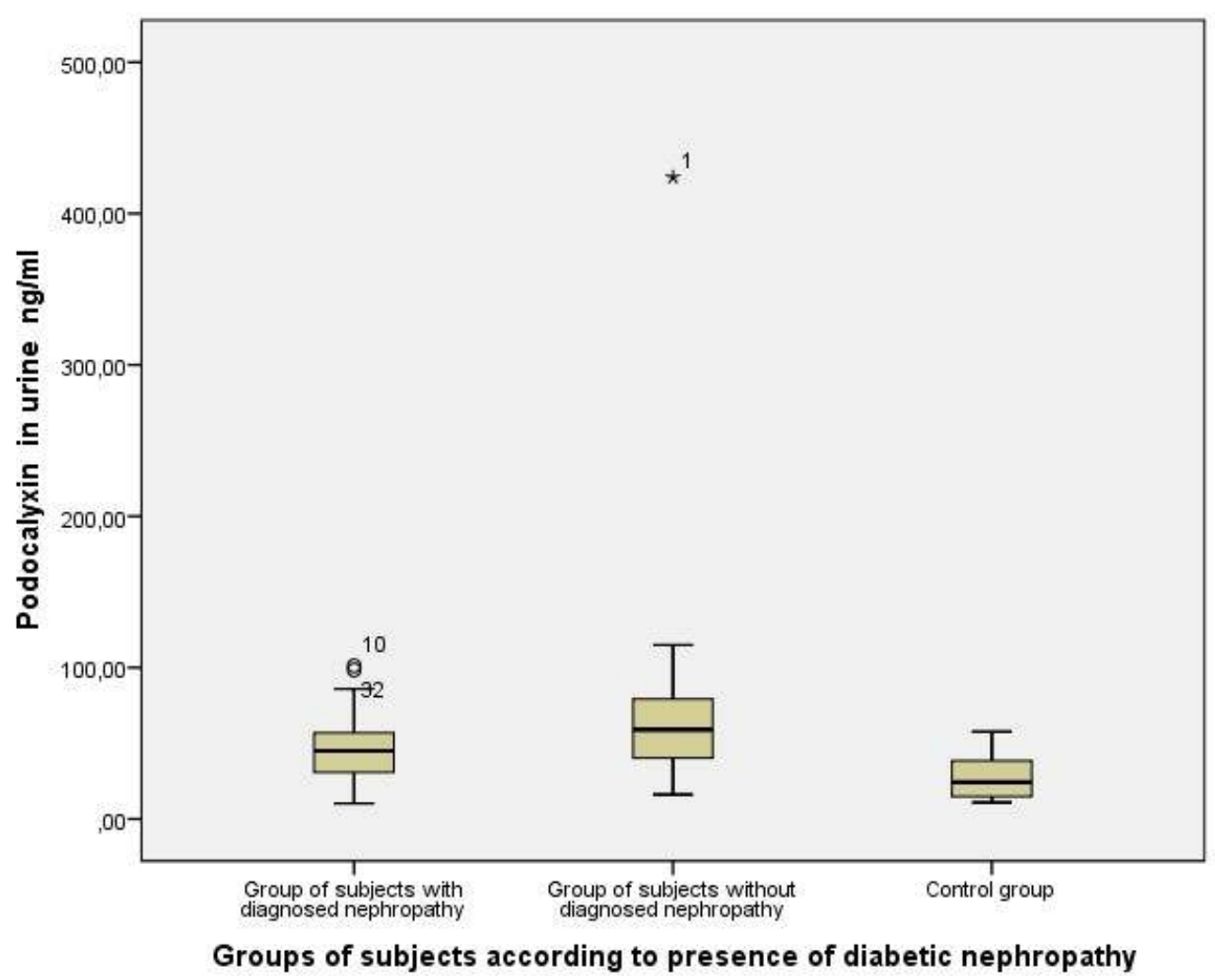

Figure 2. Comparison of u-PDX in patients with and without diagnosed DN and healthy subjects.

\section{CORRELATION BETWEEN U-PDX LEVELS AND CLINICAL AND LABORATORY DATA OF PATIENTS}

DN is identified by two laboratory tests: 1) eGFR, a measure of kidney function, and 2) $U M / C R$, a measure of kidney damage [23]. A nonparametric Kendall's tau-b ( $\mathrm{cb}$ ) correlation test was performed to determine the correlation coefficient between u-PDX levels and laboratory tests for assessment of renal function or DN. There was no correlation between eGFR and u-PDX $(\mathrm{r}=-0.061$, $\mathrm{p}=0.392)$, and a weak correlation between $\mathrm{u}-\mathrm{PDX}$ and $\mathrm{UM} / \mathrm{CR}(\mathrm{r}=0.227, \mathrm{p}=0.002)$. Furthermore, the same correlation test was used to calculate correlation between u-PDX levels and other laboratory tests and clinical data of patients.

Weak correlation was found between u-PDX and blood glucose levels, HbAlc, total protein in serum, BMI, serum creatinine, total cholesterol, triglycerides. There was no correlation between u-PDX and age, serum albumin, blood urea, and duration of disease. The correlation coeficients between u-PDX and clinical and laboratory data of patients are presented in Table 3.

Table 3

Correlation between u-PDX and clinical and laboratory data of subjects

\begin{tabular}{|l|c|c|}
\hline \multicolumn{1}{|c|}{ Clinical and laboratory data } & r & u-PDX \\
\cline { 2 - 3 } & \multicolumn{2}{|c|}{ p } \\
\hline Age $($ years) & 0.095 & 0.193 \\
\hline Duration of disease (years) & 0.133 & 0.076 \\
\hline BMI $\left(\mathrm{kg} / \mathrm{m}^{2}\right)$ & 0.207 & 0.004 \\
\hline Glucose $(\mathrm{mmol} / \mathrm{L})$ & 0.192 & 0.007 \\
\hline UM/CR $(\mathrm{mg} / \mathrm{g})$ & 0.227 & 0.002 \\
\hline HbA1c $(\%)$ & 0.144 & 0.049 \\
\hline Total proteins $(\mathrm{g} / \mathrm{L})$ & 0.157 & 0.03 \\
\hline Albumin $(\mathrm{g} / \mathrm{L})$ & 0.110 & 0.133 \\
\hline Urea $(\mathrm{mmol} / \mathrm{L})$ & -0.028 & 0.693 \\
\hline Creatinine $\left(\mu \mathrm{mol}_{\mathrm{N}} / \mathrm{L}\right)$ & 0.160 & 0.025 \\
\hline eGFR $\left(\mathrm{ml} \mathrm{min}{ }^{-1} 1.73 \mathrm{~m}^{-2}\right)$ & -0.061 & 0.392 \\
\hline
\end{tabular}

BMI - body mass index, UM/CR - urinary microalbumin to creatinine ratio, HbA1c - glycated haemoglobin A1c, eGFR - (estimated Glomerular Filtration Rate). 
MEASURES OF DIAGNOSTIC ACCURACY OF U-PDX AND UM/CR IN PATIENTS WITH DN

Non-parametric ROC analysis was used to assess the diagnostic accuracy of u-PDX and $\mathrm{UM} / \mathrm{CR}$ in patients with DN. The optimal cut-off value for u-PDX and UM/CR was detrmined from the highest Youden Index, or equivalently, the highest Sensitivity + Specificity $-1[24,25]$. The area under the ROC curve was 0.894 , CI $95 \%$ [0.817-0.972] for u-PDX and 0.63, CI 95\% [0.540-0.725] for UM/CR, respeqtively.

The results for diagnostic accuracy data for $\mathrm{UM} / \mathrm{CR}$ and $\mathrm{u}$-PDX are shown in Table 4.

Table 4

Diagnostic accuracy data for UM/CR and u-PDX

\begin{tabular}{|c|c|c|}
\hline & u-PDX & $\mathrm{UM} / \mathrm{CR}$ \\
\hline The area under the ROC curve (AUC) & 0.894 & 0.636 \\
\hline $95 \%$ Confidence interval $(95 \% \mathrm{CI})$ & $0.817-0.972$ & $0.540-0.725$ \\
\hline Significance level $\mathrm{p}($ Area $=0.5)$ & $<0.0001$ & 0.011 \\
\hline Youden index J & 0.666 & 0.3146 \\
\hline Optimal cut-off & $>43.8 \mathrm{ng} / \mathrm{ml}$ & $>30 \mathrm{mg} / \mathrm{g}$ \\
\hline Sensitivity & $73.3 \%$ & $41.5 \%$ \\
\hline Specificity & $93.3 \%$ & $90 \%$ \\
\hline NPV - negative predictive value & $72.2 \%$ & $35.5 \%$ \\
\hline PPV - positive predictive value & $91.6 \%$ & $91.4 \%$ \\
\hline Diagnostic effectiveness (accuracy) & $83.3 \%$ & $53.1 \%$ \\
\hline
\end{tabular}

ELEVATED U-PDX IN SUBGROUPS OF PATIENTS DIVIDED ACCORDING TO UM/CR

Optimal cut-off for u-PDX ( $>43.8 \mathrm{ng} / \mathrm{ml})$ was determined using ROC analysis. u-PDX was higher than the cut-off value in $48,2 \%$ of normoalbuminuric patients, in $64 \%$ of microalbuminuric patients and in $100 \%$ of macroalbuminuric patients. The results are shown in Figure 3.

u-PDX was higher than the cut-off value in $93.3 \%$ of patients with diagnosed DN and in 51.6\% of patients with T2DM without diagnosed DN.

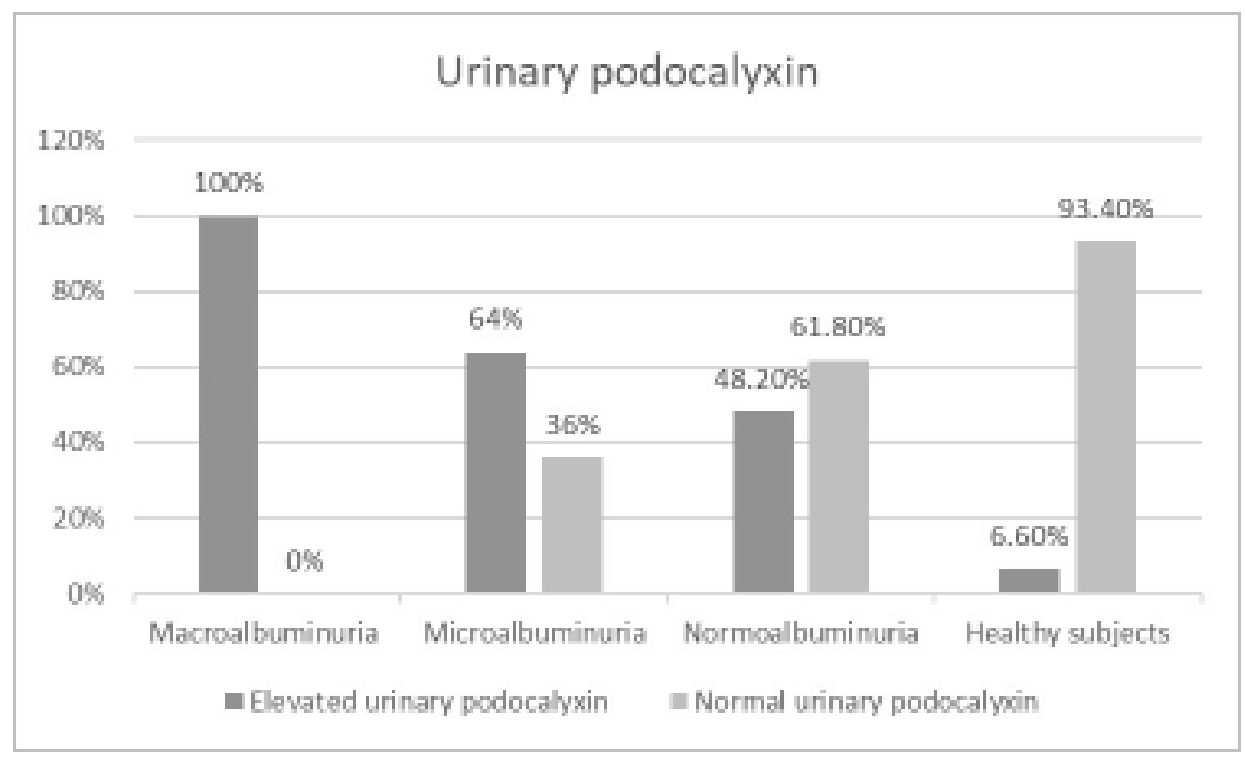

Figure 3. Percentage of subjects with elevated u-PDX in subgroups of patients divided according to UM/CR.

\section{DISCUSSION}

DN is a clinical syndrome represented by persistent albuminuria ( $>300 \mathrm{mg} / \mathrm{d}$ or $>200 \mu \mathrm{g} / \mathrm{min}$ ), confirmed on at least two occasions 3-6 months apart, progressive reduction in the GFR and elevated arterial blood pressure [20]. Microalbuminuria has been considered as a gold standard for the detection of early detection of DN. However, it is not a sufficiently accurate predictor of DN due to some limitations. Microalbuminuria lacks both sensitivity and specificity to detect the early stage of DN. Furthermore, not all patients with T2DM with microalbuminuria will end up with ESRD, and 30\% 
of them may actually have normoalbuminuria. Recent studies suggest that microalbuminuria is present once significant renal injury has already occurred $[5,26]$. Therefore, there is an urgent requirement to identify more sensitive and specific biomarkers than microalbuminuria for early detection of DN. In T2DM patients, increased levels of specific urinary biomarkers could be detected before the onset of significant microalbuminuria and they can be used as early markers of $\mathrm{DN}[15,27]$.

DN being considered as a podocytopathy and the assessment of podocyte injury can be accomplished by measurement of specific podocyte proteins such as u-PDX. The presence of microalbuminuria indicates the injury of all of these three components in GFB, while u-PDX as a specific markers for podocytes, indicate the specific podocyte injury that is unrelated to the other two elements (endothelial cells and glomerular basement membrane). It appears reasonable that damage of podocyte cells and appearance of PDX in urine precede microalbuminuria in $\mathrm{DN}[9,28]$.

Our study aimed to investigate the role of $\mathrm{u}-\mathrm{PDX}$ in early diagnosis of DN by estimating the concentrations of u-PDX in patients with T2DM. A significant difference was found regarding u-PDX levels among subgroups of patients with T2DM divided according to $\mathrm{UM} / \mathrm{CR}$ and healthy subjects. It is important to note that we found a significant difference in u-PDX levels between subgroup of subjects with normoalbuminuria and T2DM and healthy subjects. This finding confirms that the damage of podocytes occur since the early stages of DN in patients with T2DM. A similar pattern of results was obtained in other study wherein a significant elevation of urinary podocalyxin-positive elements (PCX+EL) in the early stage of DN was found [29]. Elevated u-PDX levels were observed in $48.2 \%$ of patients with normoalbuminuria, $64 \%$ of patients with microalbuminuria and $100 \%$ of patients with macroalbuminuria. Similar results were demonstrated in recent study [30]. These results indicated that PDX is present in urine in the early stage of DN, before the onset of microalbuminuria.

We observed weak positive correlation between u-PDX levels and blood glucose levels, HbAlc, total protein in serum, BMI, serum creatinine, total cholesterol, and triglycerides. We detected a weak positive correlation between u-PDX levels and UM/CR. This finding differ slightly from the result obtained in another study that reported a significant positive corelation between $\mathrm{UM} / \mathrm{CR}$ and $\mathrm{u}-\mathrm{PDX}$ [31]. eGFR did not correlate with u-PCX levels. eGFR typically reflect impaired renal function only in the advanced stages of DN. In recent study, similar finding on correlation between eGFR and u-PDX was demonstrated [32].

Roc analysis showed diagnostic accuracy $(83.3 \%)$ of u-PDX in differentiation between patients with DN and healthy subjects. Furthermore, we found high specificity (93.3\%) and sensitivity (73.3\%) of $\mathrm{u}-\mathrm{PDX}$ as a biomarker in early detection of DN. Similar accuracy of u-PDX in early detection of DN was found in a study of El-Saeed although they used podocalyxin/creatinine ratio in ROC analysis [27]. Using cut-off $30 \mathrm{mg} / \mathrm{g}$ for $\mathrm{UM} / \mathrm{CR}$ we found sensitivity $41.5 \%$, specificity $90 \%$, and diagnostic accuracy $53.1 \%$ in predicting DN. In recent study was found that UM/CR had a sensitivity of $70 \%$ and specificity of $62 \%$ in early detection of DN [33].

Our research may have two limitations. The first is the cross-sectional nature of study, and the second, the small sample size of study. Also in fact this study does not explain whether u-PDX is part of a causal mechanism or u-PDX is going to predict subsequent $\mathrm{DN}$. To answer these questions, we need an estimation of u-PDX prospectively in patients with T2DM and normoalbuminuria. We recommend further large, prospective studies to confirm the clinical utility of u-PDX as a marker for early detection of DN. If further large prospective studies research confirms that u-PDX is an earlier and more sensitive and specific marker of preclinical DN than microalbuminuria, it could be implemented in laboratory practice as a routinely marker for early detection of DN.

\section{CONCLUSION}

The results of this study show that u-PDX could be important in early detection of DN, due to the following findings: high percent of T2DM normoalbuminuric subjects with elevated levels of $\mathrm{u}-\mathrm{PDX}$ and higher diagnostic accuracy (sensitivity, specificity, NPV, PPV) of u-PDX than microalbumin in patients with DN.

We can conclude that u-PDX could be a useful and more sensitive and specific marker than microalbuminuria in early detection of DN.

Introducere. Afectarea podocitelor este o caracteristică timpurie a nefropatiei diabetice (ND), iar afectarea podocitară poate fi evaluată prin analiza podoxicalinei 
urinare. Studiul și-a propus să evalueze nivelurile podoxicalinei urinare și să determine specificitatea și sensibilitatea afectării renale precoce în $N D$.

Materiale și metode. Au fost recrutați 90 de pacienți cu diabet zaharat tip 2. 60 nu au fost diagnosticați cu ND și 30 au fost diagnosticați cu ND. 30 de martori sănătoși au fost evaluați. Pacienții cu diabet zaharat au fost împărțiți în 3 grupe după raportul microalbumină/creatinină normoalbuminuric, microalbuminuric și macroalbuminuric. Podoxicalina urinară a fost analizată prin ELISA. Sângele venos a fost recoltat pentru analize biochimice uzuale.

Rezultate. Nivelurile podoxicalinei urinare au fost mai mari la pacienții cu diabet zaharat tip 2 și nivelul a crescut odată cu progresia $N D(p=0,029)$. S-a observat o corelație pozitivă cu valoarea raportului microalbumina/creatinină $(r=0,227, p=0,002)$. O valoare prag de 43,8 $\mathrm{ng} / \mathrm{ml}$ a avut $73,3 \%$ sensibilitate și 93.3\% specificitate pentru detecția ND în stadiu precoce. $O$ valoare a raportului microalbumină/creatinină de $30 \mathrm{mg} / \mathrm{g}$ a avut 41,5\% sensibilitate și $90 \%$ specificitate pentru diagnosticul ND. Podoxicalinul a fost crescut la 48,2\% dintre pacienții microalbuminurici.

Concluzii. Podoxicalina urinară poate fi utilă pentru diagnosticul precoce al DN și pare să fie superioară microabluminuriei.

Correspondence to: Irena Kostovska, Department of Medical and Experimental Biochemistry, Faculty of Medicine, 50 Divizija 6, 1000 Skopje, North Macedonia

Phone: +38978208990

Fax: +38923230431

E-mail: irenakostovska22@yahoo.com; https://orcid.org/0000-0003-0971-6710

Acknowledgments: None declared.

Conflict of interest disclosure: The authors declare that there are no conflicts of interest.

\section{REFERENCES}

1. UMANATH K., LEWIS JB., Update on Diabetic Nephropathy: Core Curriculum 2018, Am. J. Kidney. Dis., 2018, 71(6):884-895.

2. PUGlieSE G., PENNO G., NATAli A., BARUTTA F., DI PAOLO S., REBOLDI G. et al., Diabetic kidney disease: new clinical and therapeutic issues. Joint position statement of the Italian Diabetes Society and the Italian Society of Nephrology on "The natural history of diabetic kidney disease and treatment of hyperglycemia in patients with type 2 diabetes and impaired renal function", J. Nephrol., 2020, 33(1):9-35.

3. PERSSON F., ROSSING P., Diagnosis of diabetic kidney disease: state of the art and future perspective, Kidney. Int. Suppl (2011), 2018, 8(1):2-7.

4. UWAEZUOKE SN., The role of novel biomarkers in predicting diabetic nephropathy: a review, Int. J. Nephrol. Renovasc. Dis., 2017, 10:221-231.

5. LEE SY., CHOI ME., Urinary biomarkers for early diabetic nephropathy: beyond albuminuria, Pediatr. Nephrol., 2015, 30(7):1063-1075.

6. DAI H., LIU Q., LIU B., Research Progress on Mechanism of Podocyte Depletion in Diabetic Nephropathy., J. Diabetes. Res., 2017, 2017:2615286.

7. LIAPIS H., ROMAGNANI P., ANDERS HJ., New insights into the pathology of podocyte loss: mitotic catastrophe., Am. J. Pathol. 2013, 183(5):1364-1374.

8. MATOVINOVIC MS., 3. Podocyte Injury in Glomerular Diseases., EJIFCC, 2009, 20(1):21-27.

9. NAKAMURA T., USHIYAMA C., SUZUKI S., HARA M., SHIMADA N.,EBIHARA I. et al., Urinary excretion of podocytes in patients with diabetic nephropathy, Nephrol. Dial. Transplant., 2000, 15:1379-1383.

10. WEIL EJ., LEMLEY KV., MASON CC., YEE B., JONES LI., BLOUCH K. et al., Podocyte detachment and reduced glomerular capillary endothelial fenestration promote kidney disease in type 2 diabetic nephropathy, Kidney. Int., 2012, 82(9):1010-1017.

11. FISHEA T., Urinary biomarkers for early diabetic nephropathy in type 2 diabetic patients, Biomark. Res., 2015, 3:16.

12. NAUTA FL., BOERTIEN WE., BAKKER SJL., GOOR HV., OEVEREN WV., YONG PE. et al., Glomerular and tubular damage markers are elevated in patients with diabetes, Diabetes. Care., 2011, 34:975-981.

13. KANDASAMY Y., SMITH R., LUMBERS ER., RUDD D., Nephrin - a biomarker of early glomerular injury, Biomark. Res., 2014, 2:21.

14. SEKULIC M., SEKULIC PS., A compendium of urinary biomarkers indicative of glomerular podocytopathy, Pathol. Res. Int., 2013, 2013:782395. 
15. GLUHOVSCHI C., GLUHOVSCHI G., PETRICA L., TIMAR R., VELCIOV S., IONITA I. et al., Urinary Biomarkers in the Assessment of Early Diabetic Nephropathy, J. Diabetes. Res., 2016, 2016:4626125.

16. REISER J., ALTINTAS MM., Podocytes, F1000Res, 2016, 5:F1000 Faculty Rev-114.

17. NIELSEN J., MCNAGNY K., The Role of Podocalyxin in Health and Disease, J. Am. Soc. Nephrol., 2009, 20(8):1669-1676.

18. KOSTOVSKA I., TRAJKOVSKA TK., CEKOVSKA S., SPASOVSKI G., LABUDOVIC D., Nephrin and Podocalyxin - New Podocyte Proteins for Early Detection of Secondary Nephropathies, BANTAO J., 2016, 14(1):11-16.

19. SUN D., ZHAO X., MENG L., Relationship between urinary podocytes and kidney diseases, Ren. Fail. 2012, 34(3):403-407.

20. AGARWAL R., Diabetic nephropathy, proteinuria, and progression of CKD, Clin. J. Am. Soc. Nephrol., 2009, 4:1523-1528.

21. KDIGO., Chapter 1: Definition and classification of CKD, Kidney. Int. Suppl., 2013, 3:19.

22. COCKROFT DW., GAULT MH., Prediction of creatinine clearance from serum creatinine, Nephron., 1976, 16:31-41.

23. NAVRA AS., BILOUS RW., Laboratory Assessment of Diabetic Kidney Disease, Diabetes. Spectr., 2015, 28(3):162-166.

24. ŠIMUNDIC AM., Measures of Diagnostic Accuracy: Basic Definitions, EJIFCC., 2009, 19(4):203-211.

25. HABIBZADEH F., HABIBZADEH P., YADOLLAHIE M., On determining the most appropriate test cut-off value: the case of tests with continuous results, Biochem. Med., 2016, 26(3):297-307.

26. CHIDA S., FUJITA Y., OGAWA A., HAYASHI A., ICHIKAWA R., HAYASHI A. et al., Levels of albuminuria and risk of developing macroalbuminuria in type 2 diabetes: historical cohort study, Sci. Rep., 2016, 6:26380.

27. El-SAEED GK., SHEHAB El-DEEN WA., MONTASR BA., OMAR TA., MOHAMED DS., Urinary podocalyxin and cyclophilin A: markers for early detection of type 2 diabetic nephropathy, Menoufia. Med. J., 2019, 32:996-1003.

28. Al-RUBEAAN K., SIDDIQUI K., Al-GHONAIM MA., YOUSSEF AM., Al-SHARQAWI AH., AlNAQEB D., Assessment of the diagnostic value of different biomarkers in relation to various stages of diabetic nephropathy in type 2 diabetic patients, Sci. Rep., 2017, 7(1):2684.

29. YE H., BAI X., GAO H., LI L., WU C., SUN X. et al., Urinary podocalyxin positive-element occurs in the early stage of diabetic nephropathy and is correlated with a clinical diagnosis of diabetic nephropathy, J. Diabetes. Complicat., 2014, 28:96100.

30. HARA M., YAMAGATA K., TOMINO Y., SAITO A., HIRAYAMA Y., OGASAWARA S. et al., Urinary podocalyxin is an early marker for podocyte injury in patients with diabetes: establishment of a highly sensitive ELISA to detect urinary podocalyxin, Diabetologia., 2012, 55(11):2913-2919.

31. SHOJI M., KOBAYASHI K., TAKEMOTO M., SATO Y., YOKOTE K., Urinary podocalyxin levels were associated with urinary albumin levels among patients with diabete, Biomarkers., 2016, 21(2):164-167.

32. WANG R.,YAO C., LIU F., Association between Renal Podocalyxin Expression and Renal Dysfunction in Patients with Diabetic Nephropathy: A Single-Center, Retrospective Case-Control Study, BioMed. Res. Int., 2020, Article ID 7350781.

33. BACCI MR., CHEHTER EZ., AZZALIS LA, COSTA DE AGUIAR ALVES B., FONCESKA FLA., Serum NGAL and Cystatin C Comparison With Urinary Albumin-to-Creatinine Ratio and Inflammatory Biomarkers as Early Predictors of Renal Dysfunction in Patients With Type 2 Diabetes, Kidney. Int. Rep., 2016, 2(2):152-158.

Received $25^{\text {th }}$ May 2020 